\title{
Words and Herbs: Julian Tuwim and the Poetry of Mindfulness
}

"In their home it smells like thyme, clean, lavender and language of yesteryear"1

Jacques Brel, Les Vieux, transl. Konstancja Maleszyńska

"Poetry does not belong to whoever writes it, but to whoever needs it" Il Postino, directed by Michael Radford

\section{The poetry of mindfulness in poetry therapy}

In Füves könyv, Sándor Márai declared that he wished to learn from it "from the signs of life, meaning from letters, from human heart, from grass" 2 . Therefore, he considered literature, feelings, and nature as the main signs of life. Similar convictions were expressed by those who through poetry - written and being read, including in the educational process - teach how to meditate about the world and achieve internal peace. It is worth noting the

1 As quoted in: J. Maleszyńska, Apologia piosenki. Studia z historii gatunku, Poznań 2013, p. 156. [Original version: "Chez eux ça sent le thym, le propre, la lavande et le verbe d'antan"; Polish translation: "W ich domach zapach ziół i zapach dawnych słów”; English translation posted at https://lyricstranslate.com/en/les-vieux-old-people.html]

2 S. Márai, Księga ziót, transl. F. Netz, Warsaw 2003, p. 7. The English title would read: The Book of Herbs. [Unless indicated otherwise, quotations and titles in English were translated from Polish] 
original meaning of the word 'pokój' [peace]: "silence, solace, calmness", and that it collocated with the verbs ' $k o i c$ ' [to soothe] and the already obsolete 'pokoic [to soothe - in the perfective form and meaning] ${ }^{3}$. Poetry is an undeniable ally of mindful activities in educational activities regarding the Polish language, literature, and culture ${ }^{4}$. In the article titled Poetry Therapy: Using Words to Heal, Barbara Trainin Blank noted that: "Biblio/poetry therapy, one of the creative arts therapies, consists in using the written word (although it may be read out loud) in order to bring healing and personal growth"s.

In this article, I shall focus on the lessons in mindfulness conducted among male and female primary schoolers with the use of poetic texts ${ }^{6}$. Such activities sometimes support and promote other methods of understanding poems and readers, while in other instances they become an autotelic form of work. The author devoted particular attention to poems by Julian Tuwim. They enable one to practise affirmations and share gratitude residing inside that which Joanna Niżyńska, a specialist in Miron Białoszewski's works, called "the kingdom of minorimportance" come in the form of herbs, as indicated in the title ${ }^{8}$.

${ }_{3}^{3}$ Pokój (entry), [in:] A. Brückner, Stownik etymologiczny języka polskiego, Warsaw 1970, pp. 243-244.

${ }^{4}$ As Wiktor Czernianin identified, catharsis in poetry therapy focused on the therapeutic effect, on moral 'cleansing', on mystical experience, on purely aesthetic experiences, and on hedonistic satisfaction. W. Czernianin, Catharsis in Poetry Therapy, "Polish Journal of Applied Psychology" 2013, vol. 12(2), pp. 25-38.

${ }^{5}$ B. Trainin Blank, Poetry Therapy: Using Words to Heal, https://www.socialworker.com/ feature-articles/practice/Poetry_Therapy\%3A_Using_Words_to_Heal/. Cf. Poetry Therapy: The Use of Poetry in the Treatment of Emotional Disorders, ed. J.J. Leedy, New York 1969.

${ }^{6}$ Ewa Paczoska wrote: "The path of mindfulness was followed by philosophers, as well as psychologists, who argued, like William James and Henri Bergson, that every sensation is a complex combination of memory, desire, will, expectation, and direct experience. Artists organise within their works the typical lessons of mindfulness which match this description. Painters (...) experiment with viewers' attention, they draw it to the method which breaks the perceptive habits shaped by contemporary culture and it demands mindfulness. For that same reason writers experiment, for example with a novel's time and space or change narrative strategies to put readers in the situation of cognitive uncertainty in the face of a dynamic set of sensations simulated by literature, and also in a situation of suspension of one's attention". E. Paczoska, Lekcje uważności. Moderniści i realizm, Warsaw 2018, p. 14.

${ }^{7}$ J. Niżyńka, Królestwo małoznaczności. Miron Białoszewski a trauma, codzienność i queer, transl. A. Pokojska, Kraków 2018.

${ }^{8}$ It is not my ambition to trace herbal motifs in literature or even in the Polish poetry; yet, considering the expectations of readers, I prepared a small overview. A herbarium was kept by Eliza Orzeszkowa - it can be viewed in the library of the Poznan Society for the Advancement of Arts and Sciences. Allegorical significance should be assigned to the herbs brought by Shakespeare's Ophelia (rosemary - symbol of memory, fennel - flattery, columbine - sensuality, rue - grief). Salvia and thymus can be found in the medicine store in Pan Tadeusz. The scent of herbs was taken in by the heroes of Franciszek Karpiński's pastoral poem titled Do Justyny. Tęskność na wiosnę. Czesław Miłosz thus concluded his narrative poem titled Orpheus and Eurydice, written after his wife died in 2002: "Only now everything cried to him: Euridice! / How will I live without you, my consoling one! / But there was a fragrant scent of herbs, the low humming of bees, / And he fell asleep with his cheek on the sun-warmed earth". Finally, I would like to refer readers to excerpts of poems by Tuwim's friends, members of the Skamander poetic group. "Oh, how I was tormented by the herb above other herbs, / Which nothing can resist" - wrote Jan Lechoń, while Kazimierz Wierzyński wrote in the poem titled Zabawa dziecinna: "Herbs and words, / And it will keep me, Because above everything, / Because above death / I sang them to you" (Moje pieśni). Another poem, from 
A poem which follows the model of strong emphasis on not only the need to understand the text, but also to understand the readers through the text, often becomes the atrium of a conversation. The universal language of poetry teaches people patience, mindfulness, and viewing problems from various perspectives, and it enables one to establish a deeper relationship with the internal and external worlds. The healing power of words was already known to ancient shamans and herbalists, who used them when administering their potions. School meditation through/on poems can be accompanied by collective targeted reading or creating own texts, calligraphy of a poetic work, or visualising activities associated with inter-semiotic translation, i.e. searching for music which illustrates a work or children's translation of it into the language of images (illustrations, comic strips, impressions, the internal landscape after reading).

In the book titled 'Czarodziejski pyłek', czyli metafora i bajka we wspomaganiu rozwoju małego dziecka, Agnieszak Jaszczyk and Beata Kochaniak include in the group of forms of work used at poetry lessons the methods of: the living word, personal experience, tasks to be performed, visualisations or relaxation techniques, as well as the autogenic training by Anna Polender ${ }^{9}$, or practising the Cook's position according to Dennison ${ }^{10}$. Poetry, both received and created, supports depression therapy; it helps to understand oneself and to reach harmony with the world, to read and experience one's own completeness, seeking peace; it gives comfort in mourning and it stimulates the process of healing and leaving post-traumatic stress. It can be used in the event of a conflict between children. Poetry serves as a catalyst for expressing emotions, lowering fear, escaping stupefaction; it enables one to add meaning to painful experiences in order to achieve a state of ontological and emotional security. If written by young adults, it elevates a sense of their own value and it enables them to feel agency, find strength in their own voices - particularly when its topic is weakness - and seek courage to bring forward suppressed thoughts and emotions.

Already in the late 19th century, Benjamin Rush used poetry as medicine at the psychiatric ward of a hospital in Pennsylvania. In 1969, the National Association for Poetry Therapy was established ${ }^{11}$. In the 1970s, Deobrah Alma, a poet, established a mobile poetic emergency room (emergencypoet. com), which visits schools, festivals, conferences, and city squares. In a stylised ambulance, during free consultations, guests talk about their conditions and emotions, and ten minutes later they receive a poem as aid. After the appointment, patients describe it as an uplifting experience. By the end of the 1990s, Eli Griefer managed to start group poem therapy sessions as a volunteer at Creedmore State Hospital.

the Korzec maku collection, includes the following lines: "Words dried out, herbs too, everything is past, / Sank into paper, it has no more meaning". [All lyrics translated from Polish to English for the purposes herein]

${ }^{9}$ A relaxation technique in which adults become both the coaches and the participants; it consists of identifying with the protagonist and staging events from the story in order to feel the weight of parts of the body and come into contact with one's own body.

10 A. Jaszczyk, B. Kochaniak, "Czarodziejski pyłek”, czyli metafora i bajka we wspomaganiu rozwoju małego dziecka, Kraków 2006, p. 19.

${ }^{11}$ Cf. https://www.mateuszwiszniewski.eu/terapia_poezja_.html 


\section{Mindful poetry and thematic criticism}

In an article devoted to thematic criticism, Alicja Baluchowa discussed the topic (understood as an "image-based element through which poets frame the world"12) in relation to the "writing-specific image groups which are recurring in specific writings and which can be treated as the central element of its world of imagination"13. Among thus perceived topics in the selected group of mindful poems, particular significance is attached to herbs and other medicinal elements which originate from the natural world and which dictate the images of poetic imagination. The young adults whom I studied indicated the following as the key words of mindful poetry: elements of nature, flora and fauna, body parts, a window, motifs of viewing and an encounter.

Jon Kabat-Zinn, an American professor of medicine and the originator of the stress reduction clinic and mindfulness centre, indicated in his Mindfulness for Beginners the following elements as the foundations of a mindful attitude: not judging, patience, beginner mind, and acceptance. He defined mindfulness as "a love affair - with life, with reality, and with imagination $^{\prime 14}$. At Polish schools, work with meditation (e.g. by Kabat-Zinn or Eline Snel ${ }^{15}$ ) is still a rare practice. Meanwhile, activities revolving around poetry were described - with regard to the process of turning school into a friendly place and of optimising learning conditions - by Kabat-Zinn ${ }^{16}$, Marzena Żylińska, and Timothy D. Walker. In the book titled Teach Like Finland: 33 Simple Strategies for Joyful Classrooms, the authors recommended that teachers should become mindful ${ }^{17}$, and mentioned both the practices of reading poetry for tuning down and "peace points" designed in Finnish schools ${ }^{18}$.

\section{Herbs}

Finally, let us peer into Julian Tuwim's imagination:

For a time, I collected medicinal herbs, I brought mint, rue, thymus, and flannel leaf to the city from Inowłódz meadows, I dried them and put into a bag. No one used them to treat anything. So what for? Why? Possibly

\footnotetext{
12 A. Baluchowa, Krytyka tematyczna, "Polonistyka" 1995, issue 2.

${ }^{13}$ Ibid. p. 10.

${ }^{14}$ J. Kabat-Zinn, Praktyka uważności dla początkujących, transl. J.P. Listwan, Warsaw 2014,

${ }^{15}$ E. Snel, Uważność i spokój żabki, transl. M. Falkiewicz, Warsaw 2015; E. Snel, Daj przestrzeń... i bądź blisko. Mindfulness dla rodziców i ich nastolatków, transl. M. Falkiewicz, Warsaw 2017.

${ }^{16}$ E. Snel, Uważność i spokój..., p. 238.

17 T.D. Walker, Fińskie dzieci ucza się najlepiej, Co możemy zrobić, by nasze dzieci były szczęśliwe, wierzyły w siebie i lubiły szkołę?, transl. M. Kisiel-Małecka, Kraków 2017, p. 64.

${ }_{18}$ Ibid., pp. 28, 238. In order to learn more about the importance of rest, vide also: A.D. Pellegrini, Recess: Its Role in Education and Development, London 2005. In June 2018, Amanda Moreno argued in an interview for a Chicago magazine that in order for children to acquire complex skills which they will be required to possess by the job market, they need to be able to handle stress and control their emotions better, and this is ensured by mindfulness lessons at school. She postulated: "Start with the breath and really small things you can control better, then gradually work up", https://www.chicagomag.com/city-life/June-2018/ Mindfulness-Matters-for-Kids-Too/
} 
because "it was green, it was May, and it was unnecessary" ... At the more or less same time, there was a cosmetics/fragrance frenzy. No longer would you buy sulphur or saltpetre at Mr Thorn's, but now fragrant oils: from carnations, roses, jasmine, some aromatic vinegar in which you would boil lemon peel, vanilla and laurel leaf (vegetable! vegetable!), you would mix them, try and fail, spice, you would keep them in sealed bottles... What for? I do not know. I believe to become a poet one day. ${ }^{19}$

In this fragment, the author reminisced on his youth years, but picking herbs and storing them in his poems - binding words and fragrances and mixing them - became his poetic practice, hence the titular juxtaposition of the article devoted to the poems of the author of Kwiaty polskie and other mindfulness-profiled authors. To be more accurate, hence the ability to view them within the stream of mindfulness and using them in primary school Polish lessons ${ }^{20}$, motivated by the path of education for peace (while focusing on the most specific extent of positive peace, i.e. internal harmony). Therefore, I am interested in the cooperation between the semantic fields associated with words and herbal (or, more broadly, therapeutic) props in Tuwim's poetry, and its beneficial herbal adaptation in teaching and pedagogical processes.

Tuwim's sensory description quoted at the beginning of this subsection was already reflected in a text published on 6 January, 1913, in Kurier Warszawski, i.e. in his début poem "Prośba", in which he compared two categories: vita activa (war elements) and vita contemplativa (herbal, poetic elements).

Jedni niech będą rycerze

Wojenne niech noszą szaty,

Niech mają miecze, puklerze...

...Inni niech będą jak kwiaty (...)
Let some be knights

May they carry war livery,

Let them have swords, shields...

... And let others be like flowers (...)

In another poem, Tuwim wrote about peering into flasks: "Extracts from frail herbs, / seraphic balms, / Sorcerer's tinctures, / Alchemist infusions" ${ }^{21}$. In the young adult book titled Julek. Podróże do krain wyobraźni

${ }^{19}$ J. Tuwim, Nauka szkolna i zainteresowania pozaszkolne, [in:] Pisma proza, ed. J. Stradecki, Warsaw 1964, pp. 51-52. Originally printed in: "Wiadomości Literackie" 1936, issue 9. Cf. J. Stradecki, Wkregu Skamandra, Warsaw 1977; R. Cudak, Modele odbioru poezji Skamandra: Casus Wierzyńskiego, Katowice 1986.

${ }^{20}$ Cf. J. Paszek, Wiedza o literaturze na użytek szkoty, "Teksty" 1975, issue 3, pp. 148-160; S. Burkot, B. Faron, Z. Uryga, Wiedza o literaturze na użytek szkoty, "Pamiętnik Literacki" 1975, collection 2, pp. 79-97; W. Łukszo, Praca nad utworem poetyckim na lekcjach języka polskiego w klasie VIII, Warsaw 1956; M. Inglot, Nauczać dla literatury, "Życie Literackie" 1976, issue 20; W. Okoń, Wprowadzenie do dydaktyki ogólnej, Warsaw 1987; Z. Uryga, O badaniu recepcji utworów lirycznych w szkole, $Z$ badań nad sprawnościa recepcji wierszy lirycznych w klasie maturalnej, [in:] Nowoczesne tendencje w dydaktyce literatury i języka polskiego, Rzeszów 1974; K. Wyka, Polonistyka w świetle szkoty, uczelni i nauki, "Ruch Literacki” 1961, issue 3; M. Des Loges, Przeżycie a przedmiot $w$ dziele literackim. Uwagi z pogranicza teorii dydaktyki i literatury, "Polonista" 1936, collection 2-4; K. Wyka, O czytaniu i rozumieniu wspótczesnej poezji, "Polonistyka” 1958, issue 6.

${ }_{21}$ J. Tuwim, W Barwistanie, [in:] Wiersze wybrane, ed. M. Głowiński, Wrocław 1973, p. 39. 
Juliana Tuwima, Krystyna Ratajska devoted considerable space to Tuwim's fads and his alchemist and gatherer fascinations:

(...) He began with gathering into a wicker basket pebbles, flint, beads, and shells. He assigned them magical properties. During the holidays, he sought out various medicinal herbs in the meadows of Inowłódz. He gathered mint, rue, thymus, and flannel, he dried them, put them into bags, he created albums with them. Their scent filled the flat in Andrzeja St., offering a reminder of the last holidays ${ }^{22}$. He also collected scented oils, little flasks with colour liquid, charms supposed to ensure happiness (...). ${ }^{23}$

In the monograph titled Twarz Tuwima, Piotr Matywiecki emphasised Tuwim's vitalism ${ }^{24}$ and noted: "Plants permeate (...) the world as his fifth element"25. The Warsaw-based poet and philologist considered the following as Tuwim's main plant motifs: a seed, roots, branches, twigs, leaves, flowers, fruit $^{26}$. I shall supplement this list with herbs, recognising the spiced and medicinal influence of various poems by the author of Colloquium niedzielne na ulicy. This has already been done by other researchers, who used the plant realm to derive metaphorical descriptions of the contents or structures of the poems by the Łódź-based poet - e.g. Piotr Michałowski in the article titled "Bukiet, wiecheć, ikebana: uwagi o kompozycji Kwiatów polskich"27.

\section{The alliance of poetry and mindfulness}

In his monograph titled Child's Mind. Mindfulness Practices to Help Our Children Be More Focused, Calm and Relaxed, Christopher Willard, a psychologist, thus described his first meditation:

It was a gift from my father. I was around six back then. We rowed a pontoon on the lake (...) We watched as gigantic cumuluses changed their shapes. (...) Would like to see a magic trick? (...) I can make the cloud vanish with my mind. (...) Choose a cloud. Start with a small one. (...) Now all you have to do is focus on it and breathe. With each breath you will be able to see that the cloud is getting a bit smaller. (...) Of course, now I understand that clouds form and disperse regardless of my will, yet I still remember the sensation of that moment when my breath and mind seemed the greatest powers in the world. Right after my father. ${ }^{28}$

${ }^{22}$ K. Ratajska, Julek. Podróże do krain wyobraźni Juliana Tuwima, Łódź 2013, p. 42.

${ }^{23}$ Ibid., p. 43. Cf. A. Frączek, Rany Julek. O tym, jak Julian Tuwim został poeta, illustrated by J. Rusinek, Łódź 2017.

24 P. Matywiecki, Twarz Tuwima, Warszawa 2007, p. 465.

25 Ibid., p. 470.

26 Ibid., p. 495.

27 P. Michałowski, Bukiet, wiecheć, ikebana: uwagi o kompozycji 'Kwiatów polskich', “Teksty Drugie" 1996, issue 6, pp. 113-131.

${ }^{28}$ Ch. Willard, Child's Mind. Mindfulness Practices to Help Our Children Be More Focused, Calm and Relaxed, Berkeley 2010; as quoted in: material for the Forum mindfulness dla nauczycieli, training session, 31 Aug 2008, SWPS in Warsaw, coach: Eryk Ołtarzewski, p. 5. 
Tuwim described a meditation of clouds similar to that of Willard in the poem titled "Dyzio Marzyciel", printed in various fourth-grade Polish course books (he is, actually, the most commonly suggested poet at that stage - in the same grade, pupils discuss a poem devoted to a bird peripatetic, a late nightingale). The carefree boy, usually reduced during lessons to an idler and a glutton, watches the sky:

\author{
Położył się Dyzio na łące, \\ Przygląda się niebu błękitnemu \\ I marzy: \\ „Jaka szkoda, że te obłoczki płynące \\ Nie są z waniliowego kremu... \\ A te różowe - \\ Że to nie lody malinowe... \\ A te złociste, pierzaste - \\ Że to nie stosy ciastek... \\ I szkoda, że całe niebo \\ Nie jest z tortu czekoladowego (...)"
}

Dyzio lied down in the meadow,

Watched the blue sky

And dreamt:

"What a shame that these flowing clouds

Are not made of vanilla cream...

And those pink ones -

They are not raspberry ice cream...

And those golden fluffy ones -

They are not a pile of biscuits...

And what a shame that the entire sky

Is not made of chocolate cake (...)"

A poem that is key for the article herein - as it foregrounds the binding of words and herbs - is "Sitowie". The common in Julian Tuwim's poetry saturation of poems with sensory experiences associated with the perception of nature is already present in the first stanza, in which the world of nature is represented by fragrant mint and the thick riverine bush. That image, which the poet/poetic persona remembered and recreated, is confronted with another temporal perspective, namely that herbs - through the powers of Tuwim's spell - change into words. The magical 'hocus pocus' expression originated from - if one was to trust Friedrich Kluge, the author of a 1883 German etymological dictionary - the Latin 'hoc est corpus meum' expression. This line of thinking was close to Tuwim, who considered O hokus-pokus! Hoc est corpus! as a spell of gods and poets. It also gave the title for one of his poems, i.e. "Słowo i ciało":

\begin{abstract}
Słowo ciałem się stało I mieszka między nami,

Karmię zgłodniałe ciało

Słowami jak owocami;

(...)
\end{abstract}

Słowo jest winem i miodem, Słowo jest mięsem i chlebem (...).
The word became flesh

And dwelt among us,

I feed the hungry flesh

With words like with fruit;

(...)

The word is wine and honey,

The word is meat and bread (...).

In "Sitowie", the poet found names for flowers, biblically calling them by their names, and the imagery acquires a texture with each new line: 
Wonna mięta nad wodą pachniała, kołysały się kępki sitowia, brzask różowiał i woda wiała, wiew sitowie i miętę owiał.

Nie wiedziałem, że się będę tak męczył,

słów szukając dla żywego świata, nie wiedziałem, że gdy się tak nad wodą klęczy,

to potem trzeba cierpieć długie lata.

Wiedziałem tylko, że w sitowiu są prężne, wiotkie i długie włókienka,

że z nich splotę siatkę leciutką i cienką,

którą nic nie będę łowił.

Boże dobry moich lat chłopięcych, moich jasnych świtów Boże święty! Czy już w życiu nie będzie więcej pachnącej nad stawem mięty?

Czy to już tak zawsze ze wszystkiego będę słowa wyrywał w rozpaczy, i sitowia, sitowia zwyczajnego nigdy już zwyczajnie nie zobaczę?
Fragrant scent of mint spread on the water, tufts of bulrush swayed, the dawn became pink and the water blew,

a gust wrapped the bulrush and the mint.

I did not know then that those herbs

will become words in poems years later and that I will call flowers from afar by their names, instead of simply lying on flowers on the water.

I did not know that it will pain me so much, to find words for the living world, I did not know that when you knee on the water like that, then you need to ache many years.

I only knew that in the bulrush there are springy, frail and long fibres,

that I would weave them into a light and thin net,

with which I will catch nothing.

Good god of my boyhood years, Holy God of my light dawns!

Will there in my life be no more fragrant mint on the pond?

Will I from now on always tear out words from everything in despair, and bulrush, normal bulrush I will never see again?

The Skamandrite emphasised the difference between the spontaneous spreading of sensations by nature on the one hand and words by a poet on the other; a poet, who notices, defines, picks, and transforms - sometimes with much effort, which also became the topic of the poem titled "Bagdad, 
czyli o przyszłym poecie". He struggles to find an appropriate spell, to use words without attacking the living world, to enable readers to see the bulrush through the rhymed image, like spring can be seen in spring. In "Rzecz czarnoleska", he describes a rite of passage: "The word slowly changes in its sound, / It becomes the true one"29. In "Moja rzecz", he overtly treats the poem as a product of alchemy:

Moja rzecz - przetwarzanie,

Fermentować w przemianie,

Żebym się spalał, w ogniu wyzwalał,

Żebym się w kroplę światła zespalał,

W umiłowanie.
My thing - transforming,

To ferment in transformation,

For me to burn, become free in the flames,

For me to turn into a drop of light, Into affection.

That fear of poetic text separating from the world - and of the separation of words and things - seems almost obsessive in Tuwim's poetry. Consider in this context the poem titled "Trawa", one that - in some versions - is dedicated to Irena Tuwim, the author's sister ${ }^{30}$.

Trawo, trawo do kolan!

Podnieś mi się do czoła,

Żeby myślom nie było

Ani mnie, ani pola.

Żebym ja się uzielił,

Przekwiecił do rdzenia kości

I już się nie oddzielił

Słowami od twej świeżości.

Abym tobie i sobie

Jednym imieniem mówił:

Albo obojgu - trawa,

Albo obojgu - tuwim

(T II, p. 166)
O grass, knee-high grass!

Rise to my head,

So that thoughts could not see neither me nor the field.

For me to become herbal, Flowered to my bones' core And never to separate With words from your freshness.

So I could about you and I call by one name:

Or both - grass,

Or both - tuwim

With each utterance of the word 'trawa' [grass], the poetic persona strives to match its changing nature. He begs it to touch his head, so it will reach the level of thoughts. First, he blends the words 'udzielic' [to provide] and 'zazielić' [to become/get herbal]; he desires to become like grass, he desires to become herbal, he dreams of synonymousness and coexistence of grass and Tuwim (the Greek syn means 'co', and onoma - 'name'). He also refers to the very sources of writing, as the notion of mimesis is defined as "creative imitation of nature". In his doctoral dissertation titled Poetyka Tuwima a polska tradycja literacka, Michał Głowiński thus wrote about Tuwim’s use of words:

${ }^{29}$ Idem., Wiersze wybrane, p. 75.

30 P. Michałowski, Prywatna kolekcja w depozycie fikcji: 'Kwiaty polskie' Juliana Tuwima, “Teksty Drugie" 2000, issue 3, pp. 179-195; and M. Ubranek, Wylękniony bluźnierca, Warsaw 2013. 
“(...) they possess basically a somatic nature in his works. (...) Since words equal things, consequently users of words are subject to certain obligations ${ }^{\prime \prime 31}$. In the introduction to the collection of works published within the National Library series, the researcher also noted: "Tuwim is (...) a poet open to the world, in his energetic poems a discharge occurs only when within them there appears an element of the external reality; the tension between the $I$ and the not $I$ is a fundamental fact for their composition". ${ }^{32}$

In the introduction to Antologia poezji dziecięcej, Jerzy Cieślikowski argued that poems convey "not only autonomous values important for one's childhood, but also a vision which fulfils a person's complete development. Art, as Herbert Read, an English poet and critic, argued, offers an opportunity to save man in the world of alienation, technocracy and consumption, in an era which in theory professes grand ideas yet in practice it applies cruelty" ${ }^{\prime \prime 3}$.

\section{The place of mindful poetry in the educational experiment}

As stated before, Jon Kabat-Zinn defined mindfulness as "a love affair - with life, with reality, and with imagination" ${ }^{\prime 34}$. After providing guidelines on how to retain an image of a lake in the mind, he quoted H. D. Thoreau's Walden $^{35}$, and after describing a mountain meditation, he quoted a poem by Li Po ("The birds have vanished into the sky, / and now the last cloud drains away. / We sit together, the mountain and me, / until only the mountain remains" - Li Po, KZ, 137), which enables one to intuitively read poetic texts (in fact, this is the nature of the fragment of the American writer's prose) as the essence of meditation.

Czesław Miłosz, whom Jerzy Jarzębski called "the master of the sensory presentation of the world"36, in the prose work within Piesek przydrożny

${ }_{31}$ M. Głowiński, Poetyka Tuwima a polska tradycja literacka, Warsaw 1962, p. 225.

32 Idem., Wstęp, [in:] J. Tuwim, Wiersze wybrane, ed. M. Głowiński, Wrocław 1973, p. XLVI.

${ }^{33}$ Antologia poezji dziecięcej, selected and edited by J. Cieślikowski, additional commentary and verification by G. Frydrychowicz and P. Matuszewska, Wrocław-Warsaw-KrakówGdańsk 1981, p. XXIII.

34 J. Kabat-Zinn, Praktyka uważności dla początkujących, p. 10. In Gdziekolwiek jesteś, bądź. Przewodnik uważnego życia, he indicated that the "harmony with oneself and the world" comes from "seeking who we are, from studying our own view on the world" (KZ, 19). Idem, Gdziekolwiek jesteś, bądź. Przewodnik uważnego życia, transl. H. Smagacz, Warsaw 2014, p. 19. Hereinafter when I quote the book, I shall use the KZ abbreviation with an indication of the page number. "Though the practice of mindfulness may be simple, it does not have to be easy" $(\mathrm{KZ}, 23)$. "You need to stop and be present" (KZ, 26). "Remaining aware is the best way of grasping the moment. Mindfulness means that we are awake" (KZ, 26). "If, even for a moment, you sit down to meditate, that will be a time of inaction. It is important not to confuse inaction with not doing anything. Those are two completely different things. This is about awareness and intent. Fundamentally, they are the key" (KZ, 47).

35 "Possible on the surface of the Earth there is nothing as beautiful, as pure and as expansive as a lake. Heavenly water. (...) It is a mirror that no stone can break (...); a mirror in which all dirt sinks swept away by the foggy broom of the sun - a light cloth, which does not stop any breath, but sends its own to soar as the clouds high above it and reflect in its silent bosom" (Thoreau, KZ, 140).

36 J. Jarzębski, Być samym czystym patrzeniem bez nazwy, [in:] Poznawanie Miłosza 3, 19992010, ed. A. Fiut, Kraków 2011, p. 235. 
mentioned the notion of 'mindfulness' and explained it in terms of its popular translation, namely 'uważność':

\begin{abstract}
According to a book by a Buddhist monk, which I am currently reading, the very core of Buddhist consists of mindfulness. I believe it can be translated as 'uważność' (a word which already existed in Mikołaj Rej's works) or 'bycie uważnym'. That means to consider with care that which is now instead of turning towards that which was or that which will be. Beneficial for those tormented by their consciousnesses, those reliving their past palls, beneficial for the restless who imagine fear-riddled what will happen tomorrow. I hope my poems can help readers reside in now. And I hope I myself can be cured of the illnesses of memory. ${ }^{37}$
\end{abstract}

One of the leading mindful innovations in British school (where - within a pilot programme initiated by the Ministry of Education - pupils from 370 schools learn relaxation and meditation techniques ${ }^{38}$ ) was called.$b$ and it was intended for children and young adults aged 11-18. The name of the educational project should be expanded as: stop, breathe, consciously be. Each lesson instructs how to acquire skills of mindful psychology. The programme - written by Richard Burnett, Chris Cullen, and Chris O'Neil ${ }^{39}$, all of whom are teachers - helps pupils develop positive self-evaluations, practise concentration, enables them to affix them in a moment, transfer attention to 'here and now' in a careful and accepting manner, develop peaceful relations ${ }^{40}$, and identify their own emotions and the emotions of others.

Explicitly referencing the above-mentioned programme, I called my original authorial experiment.P. (where P refers to poetry and peace). Within it, I am researching the influence of mindfulness-inclining poems on primary school female and male pupils as well as the influence of similar readings on understanding of poetry. I am interested in whether they returned to the texts on their own, whether they brought them closer to understanding themselves and to understanding poetry, and whether they had a favourite work, and if so, which one and why. The study is intended to reveal the following elements: what consequences such a 'thinking through poems' carries; whether pupils feel its therapeutic influence; whether they feel emotionally stronger; in what conditions similar poetic meditation helps them; whether there are situations when it interferes with their educational

${ }^{37}$ Cz. Miłosz, Uważność, [in:] Piesek..., p. 19. Cf. B. Śniecikowska, Poezja uważności - Czesław Miłosz i haiku, "Zagadnienia Rodzajów Literackich" 2014, collection 1, pp. 9-26; J. Błoński, Miłosz jak świat, Kraków 1998; I. Kania, Czesław Miłosz a buddyzm, "Dekada Literacka" 2011, issue 1/2; W. Kudyba, 'Zostaw ten złudny umyst'. Echa medytacji zen w poezji Czesława Miłosza, [in:] Medytacja. Postawa intelektualna, sposób poznania, gatunek dyskursu, eds. T. Kostkiewiczowa, M. Saganiak, Warsaw 2010; Cz. Miłosz, Przeciw poezji niezrozumiałej, [in:] Życie na wyspach, Kraków 1997.

38 D. Hinds, https://www.dailymail.co.uk/news/article-6663903/Thousands-pupilsgiven-meditation-lessons-help-cope-pressure.html

39 https://mindfulnessinschools.org/wp-content/uploads/2013/02/what-is-dotb-2015. pdf

${ }^{40}$ Cf. K. Hawkins, Mindful Teacher, Mindful School: Improving Wellbeing in Teaching and Learning, Los Angeles-London-New Delhi 2017. 
plan; the source of what the poems they read are; what they trigger in them; which receptive strategies they imply; how reactions to poems translate into their experiencing of the extra-textual world, which perceptive modes they trigger; and how readers transition through the phases indicated by Kazimierz Wyka in the article titled "O czytaniu i rozumieniu współczesnej poezji", namely: understanding a text, personal experiencing of a work, and intellectual framing ${ }^{41}$

Between September 2018 and June 2019, in a class of thirteen-year-olds, I conducted, among others, an exercise during which selected lessons began with sitting on the carpet or in a comfortable position on desks. The pupils are to calm down, close their eyes or look at their calming resting hands and - in this position - they listen to poems read in Polish. Only in the course of the following days did they carefully interpret selected poetic texts in the traditional manner. For the recurring readings, I selected the following texts: "Courage" by Anne Sexton, "Wiara" and "Miłość" by Czesław Miłosz, several poetic works from his anthology titled Wypisy z ksiag użytecznych (Carlos Drummond de Andrade's "In the Middle of the Road", "Wild Geese" by Mary Oliver), Zbigniew Herbert's “Kamyk", Adam Zagajewski's "Spróbuj opiewać okaleczony świat", “On Children” by Khalil Gibran, several poems by Rumi and Rabindranath Tagore - mainly from Pieśni ofiarne ("***Spodobało ci się uczynić mnie bezkresnym", "***Na morskich wybrzeżach świtów spotykają się dzieci", “***Dlaczego lampa zgasła") - "From March 1979" by Tomas Tranströmer, "***Mogliśmy się dowiedzieć od ptaków" by Pentti Saarikoski, “***My Thoughts" by Charles Reznikoff, "Dart" by Alice Oswald, "Wyjaśnienia na marginesie" by Zuzanna Ginczanka, "This Morning, I Wanted Four Legs" by Jane Hirshfield, Wisława Szymborska's "Pod jedną gwiazdką", "Może być bez tytułu"42, "Chwila", "Do serca w niedzielę" and "Chmury"43, as well as poems by Julian Tuwim, the author of "Sitowie" and "Trawa".

The possibility of including the texts by the author of "Ptasie radio" in the practice of poetic meditation and the practices of mindfulness is already foreshadowed in his surname, which - derived from poetic etymology - should be divided into 'tu-wiem' [here-I know], i.e. whilst being here, I have a complete awareness of the place and my participation in $i t^{44}$. Tuwim wrote poems which crystallised everyday epiphanies and which were a testimony to a careful reading of the signs of existence; many of those were founded in the stream which today could be referred to as ecocriticism. Such a poem enables readers to develop their relations with themselves; it becomes a lesson in mindfulness; it helps practise focusing on details, seizing the moment, and becoming absorbed in it. This enables one to have a careful look around,

\footnotetext{
${ }^{41}$ As quoted in: B. Chrząstowska, op. cit., p. 66.

42 This poem was included in the anthology: The Poetry of Impermanence, Mindfulness, and Joy, ed. John Brehm, Somerville 2017 (No Title Required, transl. S. Barańczak, C. Cavanagh).

${ }^{43}$ Cf. A. Dauksza, 'Postuchaj, jak mi prędko bije twoje serce': Afektywny potencjał poezji Wisławy Szymborskiej, “Wielogłos” 2016, issue 3, pp. 55-74.

${ }_{44}$ As a context, allow me to quote Jon Kabat-Zinn: "However, we all far too often act as if we forgot that we are here and in this situation. In each moment we find ourselves at the crossroads of here and now" $(\mathrm{KZ}, 9)$.
} 
get a sense of direction within the internal world, practise affirmation, and share gratitude. In her text titled Terapeutyczne oddziatywanie literatury, Maria Molicka notes that poetry like this can compensate - i.e. satisfy temporarily - major needs; that it constitutes a centre for relief ${ }^{45}$ and causes some fears to become allayed ${ }^{46}$.

The participants of the experiment thus wrote in the survey, referring, it would seem, mainly to the first stage of the auditory experiencing of mindful poetry and to their own pre-receptive experiences:

- 'This is a moment for myself. It enables me to compare the world from the poems to my life'.

- 'Thanks to poems I can find some peace and quiet'.

- 'Poems have a calming and relaxing effect on me'.

- 'Poetry is a medicine for calming, an ointment, and an album of memories'.

As revealed by the experiment, reading conducted within the described mode enables that which William James - one of the founders of pragmatism in literary theories - called a "fruitful relationship with reality"47. Therefore, it cannot be underestimated in the process of literary education at the primary-school level; it helps develop knowledge in the history of literature and theory of literature, and it helps structure pupils' personalities ${ }^{48}$. In the study titled Teoria literatury w szkole. $Z$ badan nad recepcja liryki, Bożena Chrząstowska concluded: "Eventually, what is important is not what pupils know about a work of literature or how they interpret it, but to what extent the work influenced their personalities (...)"49. One should note the rather intentional selections of major poems which were made by individual participants - for instance, thirteen-year-olds trying to overcome orthorexia and anorexia consistently selected "Courage" by Anne Sexton, a poem that is actually used in therapy with teenage girls suffering from these diseases.

\section{Teaching longing. In conclusion}

The indicated poems by Julian Tuwim are an invitation to the world; they thus consider the perception of reality as equally important to the perception of poetry. The fact of coming into contact with them in a world dominated by new technologies shall prove fruitful and stimulating.

${ }^{45}$ M. Molicka, Terapeutyczne oddziatywanie literatury, [in:] Tabu w literaturze $i$ sztuce dla dzieci, eds. B. Sochańska, J. Czechowska, Poznań 2012, p. 14. Cf. A. Włodarczyk, Styl terapeutyczny w pracy nauczyciela polonisty, Kraków 2007.

${ }^{46}$ Ibid., p. 17.

47 As quoted in: A. Burzyńska, M.P. Markowski, Teorie literatury XX wieku. Podręcznik, Kraków 2006, p. 479.

${ }^{48}$ Michał Paweł Markowski thus explained the notion of institution in the context of pragmatism, which is worth noting when studying primary-school Polish lessons: "An institution is a place where our experiences are being structured", p. 484.

49 B. Chrząstowska, Teoria literatury w szkole. Z badań nad recepcja liryki, Wrocław-Warsaw-Kraków-Gdańsk 1979, p. 201. 
In Neurodydaktyka, czyli nauczanie przyjazne mózgowi, Marzena Żylińska indicated various paths for creating "the best educational environment" 50 for children in Polish schools. In the remark regarding the role of poetry, she cites a maxim-like sentence by Antoine de Saint-Exupéry: "If you want your child to learn how to build ships, you need to teach them to yearn for the sea". If we want to raise peaceful children who recognise the value of literature and relationships, it is worth teaching them this kind of yearning for poetry.

\section{REFERENCES}

Antologia poezji dziecięcej, selected and edited by J. Cieślikowski, additional commentary and verification by G. Frydrychowicz and P. Matuszewska, WrocławWarsaw-Kraków-Gdańsk 1981.

Baluchowa A., Krytyka tematyczna, "Polonistyka" 1995, issue 2.

Błoński J., Miłosz jak świat, Kraków 1998.

Brückner A., Pokój (entry), [in:] Stownik etymologiczny języka polskiego, Warsaw 1970, pp. 243-244.

Burkot S., Faron B., Uryga Z., Wiedza o literaturze na użytek szkoty, "Pamiętnik Literacki” 1975, collection 2, pp. 79-97.

Burzyńska A., Markowski M.P., Teorie literatury XX wieku. Podręcznik, Kraków 2006.

Chrząstowska B., Teoria literatury w szkole. Z badań nad recepcją liryki, Wrocław-Warsaw-Kraków-Gdańsk 1979.

Cudak R., Modele odbioru poezji Skamandra: Casus Wierzyńskiego, Katowice 1986.

Czernianin W., Catharsis in Poetry Therapy, "Polish Journal of Applied Psychology" 2013, vol. 12(2), pp. 25-38.

Dauksza A., 'Postuchaj, jak mi prędko bije twoje serce': Afektywny potencjał poezji Wistawy Szymborskiej, “Wielogłos” 2016, issue 3, pp. 55-74.

Des Loges M., Przeżycie a przedmiot w dziele literackim. Uwagi z pogranicza teorii dydaktyki i literatury, "Polonista" 1936, collection 2-4.

Frączek A., Rany Julek. O tym, jak Julian Tuwim zostat poeta, illustrated by J. Rusinek, Łódź 2017.

Głowiński M., Poetyka Tuwima a polska tradycja literacka, Warsaw 1962.

Hawkins K., Mindful Teacher, Mindful School: Improving Wellbeing in Teaching and Learning, Los Angeles-London-New Delhi 2017.

Hinds D., https://www.dailymail.co.uk/news/article-6663903/Thousands-pupilsgiven-meditation-lessons-help-cope-pressure.html

Inglot M., Nauczać dla literatury, "Życie Literackie” 1976, issue 20.

Jarzębski J., Być samym czystym patrzeniem bez nazwy, [in:] Poznawanie Miłosza 3, 19992010, ed. A. Fiut, Kraków 2011.

Jaszczyk A., Kochaniak B., "Czarodziejski pyłek”, czyli metafora i bajka we wspomaganiu rozwoju małego dziecka, Kraków 2006.

Kabat-Zinn J., Gdziekolwiek jesteś, bądź. Przewodnik uważnego życia, transl. H. Smagacz, Warsaw 2014.

${ }^{50}$ M. Żylińska, Neurodydaktyka, czyli nauczanie przyjazne mózgowi, Toruń 2013, p. 245. 
Kabat-Zinn J., Praktyka uważności dla początkujących, transl. J.P. Listwan, Warsaw 2014. Kania I., Czesław Miłosz a buddyzm, "Dekada Literacka" 2011, issue 1-2.

Kudyba W., 'Zostaw ten złudny umyst'. Echa medytacji zen w poezji Czesława Miłosza, [in:] Medytacja. Postawa intelektualna, sposób poznania, gatunek dyskursu, eds. T. Kostkiewiczowa, M. Saganiak, Warsaw 2010.

Łukszo W., Praca nad utworem poetyckim na lekcjach języka polskiego w klasie VIII, Warsaw 1956.

Maleszyńska J., Apologia piosenki. Studia z historii gatunku, Poznań 2013.

Márai S., Księga ziót, transl. F. Netz, Warsaw 2003.

Matywiecki P., Twarz Tuwima, Warszawa 2007.

Michałowski P., Bukiet, wiecheć, ikebana: uwagi o kompozycji 'Kwiatów polskich', “Teksty Drugie" 1996, issue 6, pp. 113-131.

Michałowski P., Prywatna kolekcja w depozycie fikcji: 'Kwiaty polskie' Juliana Tuwima, “Teksty Drugie" 2000, issue 3, pp. 179-195.

Miłosz Cz., Przeciw poezji niezrozumiałej, [in:] Życie na wyspach, Kraków 1997.

Molicka M., Terapeutyczne oddziatywanie literatury, [in:] Tabu w literaturze $i$ sztuce dla dzieci, eds. B. Sochańska, J. Czechowska, Poznań 2012

Niżyńka J., Królestwo małoznaczności. Miron Białoszewski a trauma, codzienność i queer, transl. A. Pokojska, Kraków 2018.

Okoń W., Wprowadzenie do dydaktyki ogólnej, Warsaw 1987.

Paczoska E., Lekcje uważności. Moderniści i realizm, Warsaw 2018.

Paszek J., Wiedza o literaturze na użytek szkoty, “Teksty” 1975, issue 3, pp. 148-160.

Pellegrini A.D., Recess: Its Role in Education and Development, London 2005.

Poetry Therapy: The Use of Poetry in the Treatment of Emotional Disorders, ed. J.J. Leedy, New York 1969.

Ratajska K., Julek. Podróże do krain wyobraźni Juliana Tuwima, Łódź 2013.

Snel E., Daj przestrzeń... i bądź blisko. Mindfulness dla rodziców i ich nastolatków, transl. M. Falkiewicz, Warsaw 2017.

Snel E., Uważność i spokój żabki, transl. M. Falkiewicz, Warsaw 2015.

Stradecki J., W kregu Skamandra, Warsaw 1977.

Śniecikowska B., Poezja uważności - Czesław Miłosz i haiku, "Zagadnienia Rodzajów Literackich" 2014, collection 1, pp. 9-26.

The Poetry of Impermanence, Mindfulness, and Joy, ed. John Brehm, Somerville 2017.

Trainin Blank B., Poetry Therapy: Using Words to Heal, https://www.socialworker. com/featurearticles/practice/Poetry_Therapy\%3A_Using_Words_to_Heal/

Tuwim J., Nauka szkolna i zainteresowania pozaszkolne, [in:] Pisma proza, ed. J. Stradecki, Warsaw 1964.

Tuwim J., Wiersze wybrane, ed. M. Głowiński, Wrocław 1973.

Ubranek M., Wylękniony bluźnierca, Warsaw 2013.

Uryga Z., O badaniu recepcji utworów lirycznych w szkole, Z badań nad sprawnościa recepcji wierszy lirycznych w klasie maturalnej, [in:] Nowoczesne tendencje w dydaktyce literatury i języka polskiego, Rzeszów 1974.

Walker T.D., Fińskie dzieci uczą się najlepiej, Co możemy zrobić, by nasze dzieci były szczęśliwe, wierzyly w siebie i lubity szkotę?, transl. M. Kisiel-Małecka, Kraków 2017.

Willard Ch., Child's Mind. Mindfulness Practices to Help Our Children Be More Focused, Calm and Relaxed, Berkeley 2010.

Włodarczyk A., Styl terapeutyczny w pracy nauczyciela polonisty, Kraków 2007. 
Wyka K., O czytaniu i rozumieniu współczesnej poezji, "Polonistyka" 1958, issue 6.

Wyka K., Polonistyka w świetle szkoły, uczelni i nauki, "Ruch Literacki" 1961, issue 3. Żylińska M., Neurodydaktyka, czyli nauczanie przyjazne mózgowi, Toruń 2013.

\section{SUMMARY}

In this article, the author discusses the subject of pro-peace education with the use of poetry, and its influence on the mental well-being of children. She indicates Julian Tuwim as one of the Polish trailblazers of the 20th-century trend of mindfulness, which instructs how to establish a harmonious relationship with oneself and the environment. She discusses studies which focus on the methods used when working during school lessons of the Polish language; methods which employ mindful poetry. The author argues that there exists a relationship between internal equanimity and global peace.

\section{Keywords}

mindful poetry, mindfulness, Julian Tuwim

Joanna Roszak - Ph.D. hab., professor at the Institute of Slavic Studies, Polish Academy of Sciences; co-founder and vice-president of the Joseph Rotblat Foundation, a poet, and a teacher. She recently published: Miejsce i imię. Poeci niemieckojęzyczni żydowskiego pochodzenia, Słyszysz? Synagoga. Wychodząc spod poznańskiej synagogi przy Wronieckiej, as well as Żuraw z origami. Opowieść o Józefie Rotblacie.

e-mail: joannamroszak@gmail.com 